\title{
Effect of Sodium Caseinates Addition on the Rheological Properties of Kefir during Gel Formation
}

\author{
Kleio D. Antoniou ${ }^{1}$, Stylianos Exarhopoulos ${ }^{1}$, Stylianos N. Raphaelides ${ }^{1}$, Georgia Dimitreli ${ }^{1} \&$ Apostolos S. \\ Thomareis $^{1}$ \\ ${ }^{1}$ Department of Food Technology, Alexander Technological Educational Institute of Thessaloniki, P.O. Box 141, \\ GR 57400, Thessaloniki, Greece \\ Correspondence: Georgia Dimitreli, Department of Food Technology, Alexander Technological Educational \\ Institute of Thessaloniki, P.O. Box 141, GR 57400, Thessaloniki, Greece. Tel: 30-231-001-3886. Fax: \\ 30-231-079-1375. E-mail: dimitrel@food.teithe.gr
}

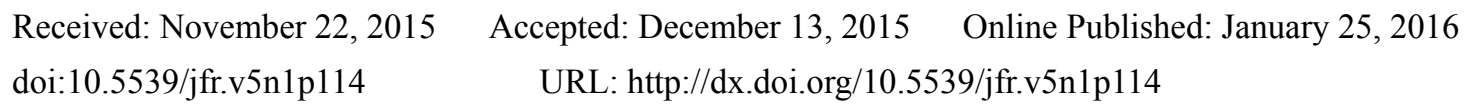

\begin{abstract}
The effect of Sodium Caseinates (SCN) addition on the rheological behavior of kefir during gel formation was monitored by means of a dynamic rheometer of novel design (U-tube Rheometer). Kefir samples were prepared from homogenized and pasteurized full fat $(3.5 \% \mathrm{w} / \mathrm{w})$ bovine milk with or without the addition of SCN at varying concentrations $(1 \%, 2 \%$ or $3 \% \mathrm{w} / \mathrm{w})$. A fermented milk inoculum derived from kefir grains was inoculated into the heat-treated milk and incubated at $25^{\circ} \mathrm{C}$ until the $\mathrm{pH}$ dropped to 4.6 . According to the results, the fermentation time required for the onset of gelation, as well as for the $\mathrm{pH}$ value to reach 4.6 increased with increasing SCN concentration. The beginning of cross-linking of proteins towards aggregates that leads to the formation of a three-dimensional protein matrix, took place at higher $\mathrm{pH}$ values with increasing SCN concentration. The values of elastic modulus and loss tangent that correspond to this point decreased with increasing SCN content. The increase in SCN concentration caused the values of elastic modulus during gel formation to increase and those of loss tangent to decrease. The addition of caseins into the milk increased the number and the strength of the protein-protein interactions causing the elastic behavior of the samples to increase. The presence of SCN into the system of kefir greatly affected the formation of the kefir gel.
\end{abstract}

Keywords: kefir, sodium caseinates, gel formation, U-tube rheometer, viscoelastic properties

\section{Introduction}

Kefir is a fermented dairy product produced by the fermentative activity of kefir grains consisting mainly of lactococci, lactobacilli and yeasts in a protein-polysaccharide matrix (Koroleva, 1988; Farnworth, 2005). As kefir is reported to be beneficial to health and due to its nutritional and favorable organoleptic characteristics (Otles \& Cagindi, 2003), the study of the factors affecting the rheological properties of the gel during formation is of great importance since they affect the quality of the final product and thus its acceptance by the consumers.

Among the many factors studied, chemical composition (mainly concentration of proteins) of the milk used affects the formation of the protein matrix and thus the rheological behavior of the final product. The addition of skim milk powder, sodium caseinates $(\mathrm{SCN})$ or whey proteins concentrates is usually aims in increasing the dry matter content of the milk and of course in improving its consistency and texture of fermented milk products (Lucey, 2004a; Tamime \& Robinson, 2007). According to Dimitreli and Antoniou (2011), SCN addition caused the apparent viscosity of kefir samples to increase and their flow behavior index values to decrease. Caseins possess an important role in the fermentation process of kefir, since they form the continuous matrix that holds together all the constituents of milk.

The study of the gelation process of yogurt (Haque, Richardson, \& Morris, 2001; Lee \& Lucey, 2006; Ozcan-Yilsay, Lee, Horne, \& Lucey, 2007; Lazaridou, Serafeimidou, Biliaderis, Moschakis, \& Tzanetakis, 2014; Ozcan, Horne, \& Lucey, 2015), other fermented dairy products (Lucey \& Singh, 1998; Peng, Horne, \& Lucey, 2010; Kristo, Miao, \& Corredig, 2011) or glucono- $\delta$-lactone induced acid milk gels (Lakemonda \& van Vliet, 2008) was made so far, by using the concentric cylinder geometry of an oscillating rheometer for the in situ preparation of the samples and the measurement of their viscoelastic properties. Nevertheless the gel of fermented milk products is extremely fragile and especially during fermentation structure formation could be 
easily disrupted if the gel matrix suffered a certain mechanical disturbance. Additionally, the rather small quantity of sample contained in the measuring unit of an oscillating rheometer combined with the possible slip effects, due to whey separation, may lead minute phenomena, taking place especially at the early stages of the gelation process, to go unnoticed.

Bearing in mind the above, a novel custom made pneumatic dynamic U-tube rheometer (Xu \& Raphaelides, 2005) was constructed to monitor the structure formation of the kefir gel. The rheometer, based on the U-tube technique of Saunders and Ward (1953), consists of two identical limbs where the sample is loaded, an air chamber whose pressure is measured by two transducers and a reciprocating piston creating a driving pressure resulting in to sample deformations and consequently to pressure increments in the air chamber on the other side of the U-tube. From these pressure measurements the rheological characteristics of the sample can be determined. An important asset of the design is the adaptive nature of the acting pressure arising from a back pressure, which allows measurements to be made on liquids as thin as water yet keeping the maximum strain within the limit of linear viscoelasticity, by adapting its value according to the rigidity of the material exhibited at the moment of measurement. Finally, the interior of the sample holder has been profiled to a screw thread shape for preventing sample slippage. This instrument has already been used in order to study the structure development of set-type yogurt (Xu, Emmanouelidou, Raphaelides, \& Antoniou, 2008).

The aim of the present work was to study the effect of SCN addition on the rheological behavior of kefir during gel formation. The structure formation of the kefir gel was monitored, by the use of the dynamic U-tube rheometer of novel design. The elastic modulus and loss tangent were recorded as a function of time and $\mathrm{pH}$. The development of the elastic modulus will contribute to the study of the effect of SCN addition on the structure formation of kefir as well as on the pattern of its gel formation. Loss tangent will give an indication of whether a phase transition is occurring to the system (from liquid to gel) during fermentation.

\section{Materials and Methods}

\subsection{Materials}

The kefir samples were prepared with full-fat $(3.5 \% \mathrm{w} / \mathrm{w})$ pasteurized and homogenized bovine milk purchased from the local dairy, kefir grains obtained from a household and SCN (MIPRODAN 30; Arla Food Ingredients, Viby J., Denmark). The chemical composition of SCN (\% w/w) was: moisture $\leq 6.0$; proteins 88.0-93.5; fat 1.5; ash 4.0; lactose 0.3.

\subsection{Preparation of Kefir Samples}

The SCN were added into the milk before its heat-treatment at varying concentrations $(1 \%, 2 \%$ or $3 \% \mathrm{w} / \mathrm{w})$, and dissolved in a Grant GLS400 shaking water-bath (Grant Instruments Ltd, Cambridge, G.B.) under continuous stirring for $20 \mathrm{~min}$ at $35^{\circ} \mathrm{C}$. The milk with or without the addition of $\mathrm{SCN}$ was heated at $85^{\circ} \mathrm{C}$ for 15 min under continuous stirring (Grant GLS400) and then cooled down at room temperature $\left(25^{\circ} \mathrm{C}\right)$. Following heat-treatment, the milk was inoculated with a fermented milk inoculum, at $3 \%(\mathrm{w} / \mathrm{w})$ ratio, derived from the household kefir grain culture (the kefir grains were inoculated into the milk at the same ratio and fermented until a $\mathrm{pH}$ of 4.6 was achieved). A quantity of approximately $100 \mathrm{~mL}$ of the inoculated milk was placed inside the measuring unit of the U-tube rheometer, while a smaller one was poured into a beaker (for $\mathrm{pH}$ measurements), which was placed into a very small $(25 \times 30 \times 25 \mathrm{~cm})$ custom made incubation chamber and kept at the same temperature as the rheometer's measuring unit. The samples were incubated at $25^{\circ} \mathrm{C}$ until the $\mathrm{pH}$ dropped to 4.6. All samples were replicated two times.

\subsection{Rheological Measurements}

The free surface of the sample placed inside the measuring unit of the U-tube rheometer was covered with a thin layer of liquid paraffin oil to avoid possible evaporation. The sample was incubated by setting the rheometer's heating unit at $25^{\circ} \mathrm{C}$. The frequency of oscillation was set at $0.1 \mathrm{~Hz}$ and every $10 \mathrm{~min}$, measurements of elastic modulus $\left(\mathrm{G}^{\prime}\right)$, loss tangent $(\tan \delta)$, incubation temperature and $\mathrm{pH}$ were taken and automatically recorded via the rheometer's microprocessor control unit. The data were shown and stored in a PC which was connected to the rheometer. From the data recorded, the fermentation time required for the onset of gelation ( $\mathrm{G}^{\prime}$ started to increase) $\left(\mathrm{t}_{\mathrm{g}}\right)$, the $\mathrm{pH}$ value at the onset of gelation $\left(\mathrm{pH}_{\mathrm{g}}\right)$, the maximum value of $\tan \delta\left(\tan \delta_{\max }\right)$, the fermentation time at $\tan \delta_{\max }\left(\mathrm{t}_{\tan \delta \max }\right)$, the $\mathrm{pH}$ at $\tan \delta_{\max }\left(\mathrm{pH}_{\tan \delta \max }\right)$, the $\mathrm{G}^{\prime}$ at $\tan \delta_{\max }\left(\mathrm{G}_{\tan \delta \max }^{\prime}\right)$, the fermentation time for the $\mathrm{pH}$ to reach the 4.6 value $\left(\mathrm{t}_{\mathrm{total}}\right)$ and the maximum value of $\mathrm{G}^{\prime}\left(\mathrm{G}_{\max }^{\prime}\right)$ were evaluated.

\subsection{Determination of the $p H$}

The $\mathrm{pH}$ measurements were carried out by inserting a combined $\mathrm{pH}$ electrode into the sample contained in the beaker which was placed inside the incubation chamber that was kept at the same temperature as the rheometer's 
measuring unit. Both the incubation temperature and the $\mathrm{pH}$ measuring unit were controlled by the rheometer's microprocessor.

\subsection{Statistical Analysis}

The experimental data were subjected to one-way ANOVA, while the Tukey multiple comparison test determined whether statistically significant differences occurred among means. The statistical analysis of the experimental data was performed using Minitab 16.0 statistical software.

\section{Results and Discussion}

\subsection{Structure Development}

Figure 1 shows the development of $\mathrm{G}^{\prime}$ of kefir samples, prepared with or without the addition of SCN, until the $\mathrm{pH}$ dropped to 4.6. As it can be seen the fermentation time required for the onset of gelation as well as for the $\mathrm{pH}$ value to reach 4.6 increased with increasing SCN concentration. The increase in fermentation time with increasing SCN concentration is due to the increased buffering capacity of the system because of the presence of caseins. Caseins possess high buffering capacity (Salaün, Mietton, \& Gaucheron, 2005) that results in more lactic acid production in order to reduce the $\mathrm{pH}$ of the samples, resulting in increased fermentation times. Furthermore, the increasing SCN concentration resulted in increased values of the G' (Figure 1). The addition of caseins into the milk system increases the possibility of either bigger or more casein clusters being formed during fermentation resulting in increased elasticity of the protein matrix. According to Walstra, Wouters and Geurts (2006), there is a power-law relation between the casein concentration and the consistency of the casein-containing systems.

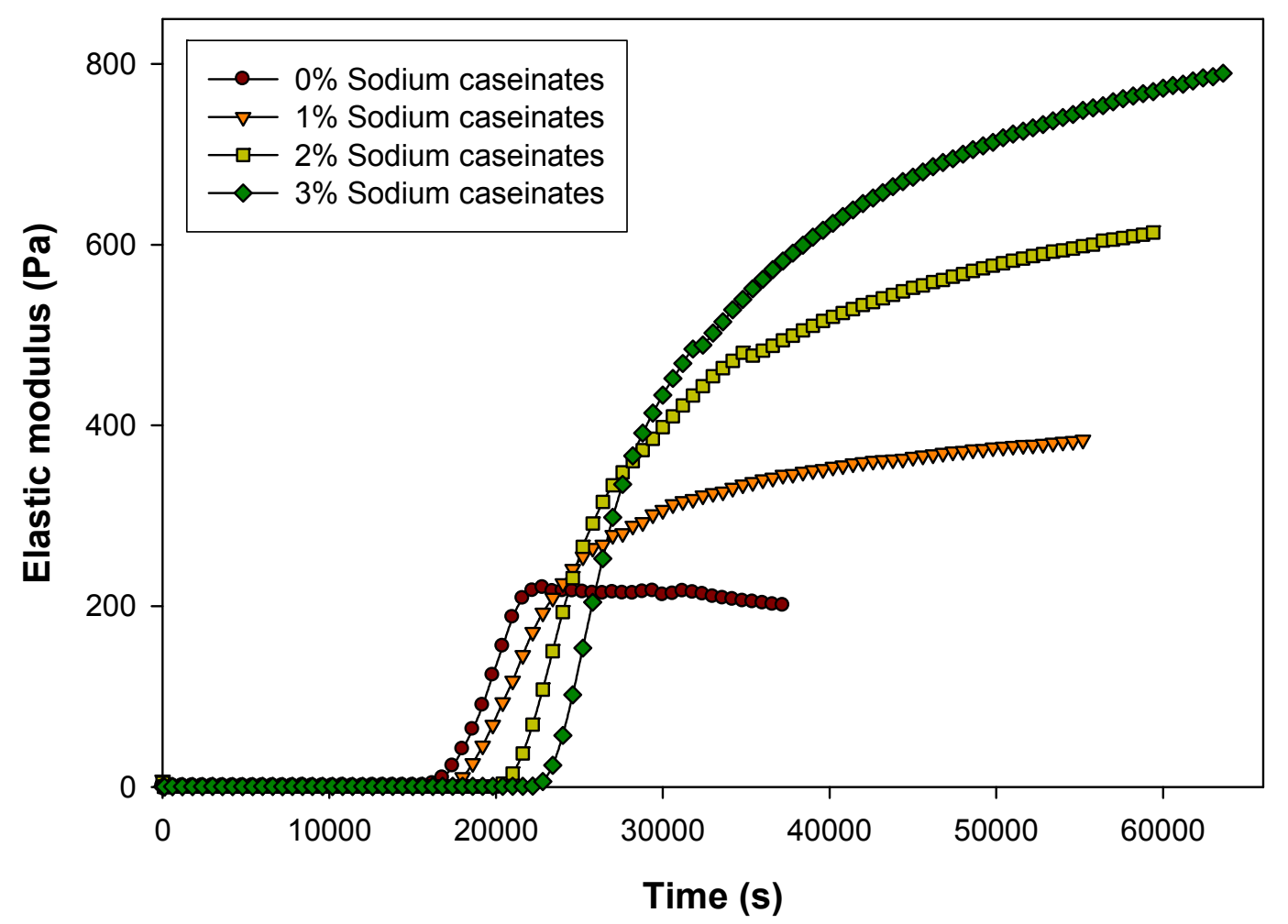

Figure 1. Development of the elastic modulus at $0.1 \mathrm{~Hz}$, with time (to final $\mathrm{pH}$ value 4.6), for kefir samples prepared with or without the addition of sodium caseinates

As it can be seen in Figure 2, at the initial stages of gel formation tan $\delta$ increases to a maximum value, which indicates the dissociation of colloidal calcium phosphate from the casein micelles. The subsequent reduction in $\tan \delta$ reflects the cross-linking of proteins and the formation of aggregates that increase in number and size leading to the formation of a three-dimensional protein matrix (the values of tan $\delta$ are almost being stabilized). The stabilization of $\tan \delta$ values indicates that the system being formed is rather stable and no structure rearrangement is occurring. According to Mellema, Walstra, van Opheusden and van Vliet (2002), higher values 
of $\tan \delta$ result in higher rate of rearrangements. During milk acidification, the reduction in $\mathrm{pH}$ results in colloidal calcium phosphate dissociation from the casein micelles into the milk serum (Walstra et al., 2006). This causes the reduction in casein micelles size, which in turn results in more liquid-like behavior of the aggregates formed, indicated by the high values of $\tan \delta$, at the initial stages of gel formation. The magnitude of $\tan \delta$ is a measure of the liquid-like behavior of a casein gel (Mellema et al., 2002). When all the amount of the colloidal calcium phosphate has been dissociated from the micelles around pH 5.0 (Lucey, 2004b), no reduction in casein micelles size is occurring. Simultaneously, the successive decrease in $\mathrm{pH}$, close to the isoelectric point of proteins, increases the number of interactions formed as well as their strength. This results in increasing the size of the aggregates formed and thus the solid-like behavior of the samples (the values of $\tan \delta$ are being decreased). The stabilization of $\tan \delta$ values probably takes place when a rather increased number of aggregates have been formed.

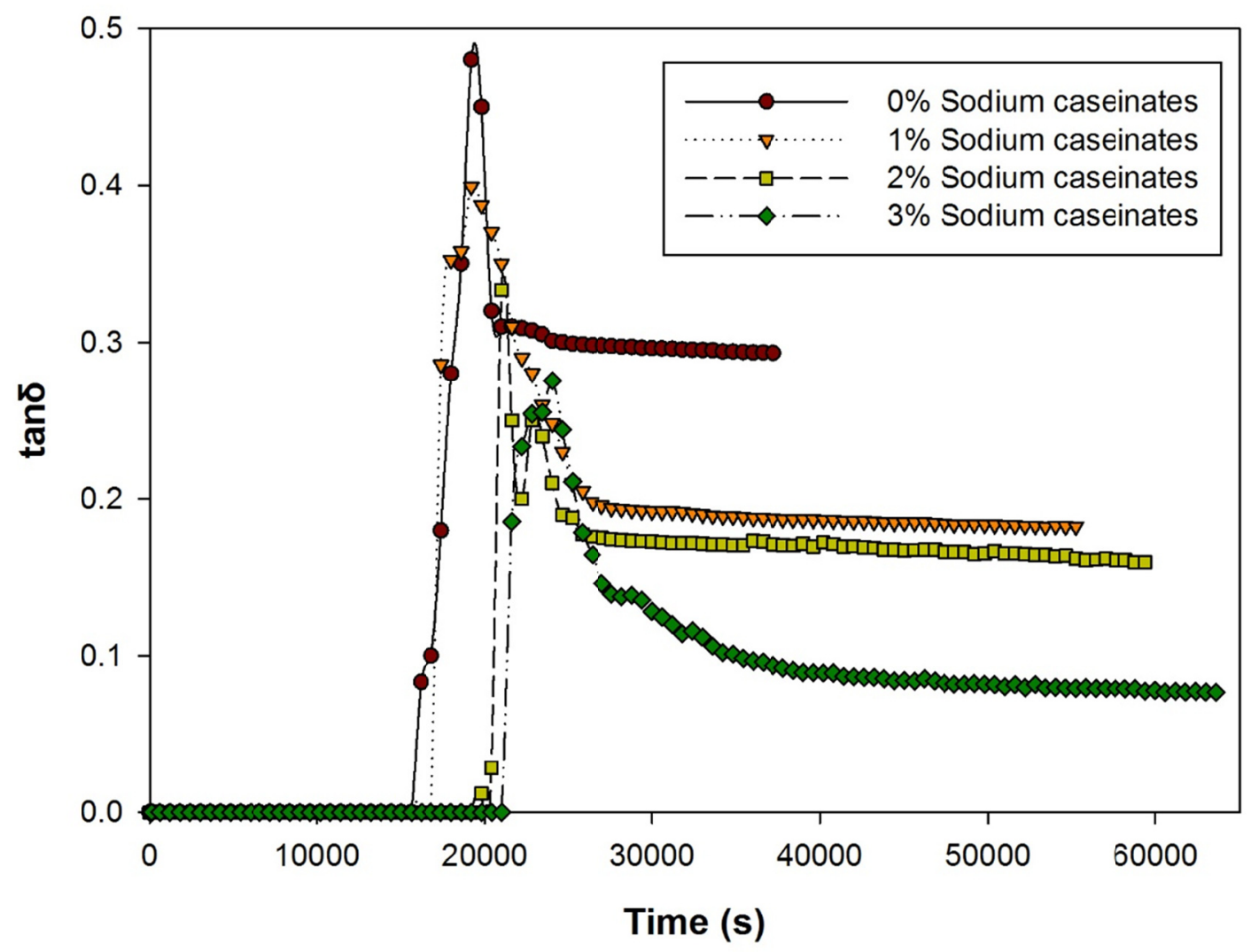

Figure 2. The values of $\tan \delta$ at $0.1 \mathrm{~Hz}$, with time (to final $\mathrm{pH}$ value 4.6), for kefir samples prepared with or without the addition of sodium caseinates

\subsection{Rheological Properties and Parameters during Gel Formation}

The rheological properties and parameters derived from the dynamic measurements during gel formation $\left(\mathrm{t}_{\mathrm{g}}, \mathrm{pH}_{\mathrm{g}}\right.$, $\tan \delta_{\max }, \mathrm{t}_{\tan \delta \max }, \mathrm{pH}_{\text {tanómax }}, \mathrm{G}_{\text {tanomax }}^{\prime}, \mathrm{t}_{\text {total }}$ and $\mathrm{G}_{\max }^{\prime}$ ) are shown in Table 1. Statistical analysis of the experimental data confirmed the findings discussed in section 3.1. According to ANOVA, all the variables examined were significantly affected by SCN addition $(\mathrm{p}<0.001)$.

Particularly, increasing SCN concentration resulted in increased $t_{g}$ and $t_{\text {total }}$ values due to the increased buffering capacity of caseins. The Tukey test showed that both $\mathrm{t}_{\mathrm{g}}$ and $\mathrm{t}_{\text {total }}$ increased in the following order: $0 \% \mathrm{SCN}<1 \%$ $\mathrm{SCN}<2 \% \mathrm{SCN}<3 \% \mathrm{SCN}$. Similar results, as it concerns the fermentation time required for the $\mathrm{pH}$ to reach 4.6 , have been reported for stirred yogurt made from buffalo milk and enriched with different concentrations of SCN (Petridis, Dimitreli, Chrysalidou, \& Akakiadou, 2013).

The $\mathrm{pH}_{\mathrm{g}}$ at the onset of gelation decreased with increasing SCN concentration. According to Tukey test, the $\mathrm{pH}_{\mathrm{g}}$ values decreased in the following order: $1 \% \mathrm{SCN}=0 \% \mathrm{SCN}>2 \% \mathrm{SCN}=3 \% \mathrm{SCN}$. The onset of gelation is due to the charge reduction of protein molecules resulting in protein-protein interaction, as the molecules come in 
contact with each other. In heat-treated milks due to the denatured whey proteins that form complexes with caseins (Lucey, Munro, \& Singh, 1998a), the destabilization of proteins takes place at higher $\mathrm{pH}$ values, when compared to unheated milk (Lucey, Tamehana, Singh, \& Munro, 1998b). This is caused by the higher isoelectric point of the whey proteins ( $\mathrm{pH}$ 5.2) when compared to caseins ( $\mathrm{pH}$ 4.6) (Lucey et al., 1998b). As the concentration of SCN is increased, the casein micelles are increased in number resulting in decreased ratio of casein-whey protein complexes to free caseins. This means that the destabilization of proteins will start at lower $\mathrm{pH}$ due to the increased casein molecules.

Table 1. The mean values of the fermentation time required for the onset of gelation $\left(\mathrm{t}_{\mathrm{g}}\right)$, the $\mathrm{pH}$ at the onset of gelation $\left(\mathrm{pH}_{\mathrm{g}}\right)$, the maximum $\tan \delta\left(\tan \delta_{\max }\right)$, the time at $\tan \delta_{\max }\left(\mathrm{t}_{\tan \delta \max }\right)$, the $\mathrm{pH}$ at $\tan \delta_{\max }\left(\mathrm{pH}_{\tan \delta \max }\right)$, the elastic modulus $\left(\mathrm{G}^{\prime}\right)$ at $\tan \delta_{\max }\left(\mathrm{G}_{\text {tanomax }}^{\prime}\right)$, the fermentation time for the $\mathrm{pH}$ to reach the $4.6\left(\mathrm{t}_{\text {total }}\right)$ and the maximum elastic modulus $\left(\mathrm{G}_{\max }^{\prime}\right)$. The standard deviations are given in parenthesis

\begin{tabular}{ccccccccc}
\hline $\begin{array}{c}\text { Sodium } \\
\begin{array}{c}\text { Caseinates } \\
\text { concentration } \\
(\% \boldsymbol{w} / \boldsymbol{w})\end{array}\end{array}$ & $\begin{array}{c}\mathbf{t}_{\mathbf{g}} \\
\mathbf{( s )}\end{array}$ & $\mathbf{p H} \mathbf{H}_{\mathbf{g}}$ & $\mathbf{t a n}_{\max }$ & $\begin{array}{c}\mathbf{t}_{\text {tanomax }} \\
(\mathbf{s})\end{array}$ & $\mathbf{p \mathbf { H } _ { \text { tanomax } }}$ & $\begin{array}{c}\mathbf{G}_{\text {tanomax }}^{\prime} \\
(\mathbf{P a})\end{array}$ & $\begin{array}{c}\mathbf{t}_{\text {total }} \\
(\mathbf{s})\end{array}$ & $\begin{array}{c}\mathbf{G}_{\max }^{\prime} \\
(\mathbf{P a})\end{array}$ \\
\hline 0 & 16200 & 5.48 & 0.480 & 19200 & 5.13 & 90.2 & 36000 & 220 \\
& $( \pm 283)$ & $( \pm 0.01)$ & $( \pm 0.004)$ & $( \pm 293)$ & $( \pm 0.01)$ & $( \pm 0.6)$ & $( \pm 324)$ & $( \pm 9)$ \\
1 & 17400 & 5.52 & 0.399 & 19400 & 5.30 & 45.6 & 55200 & 384 \\
& $( \pm 141)$ & $( \pm 0.01)$ & $( \pm 0.008)$ & $( \pm 424)$ & $( \pm 0.01)$ & $( \pm 1.0)$ & $( \pm 310)$ & $( \pm 4)$ \\
2 & 20400 & 5.38 & 0.333 & 21000 & 5.33 & 14.7 & 58200 & 610 \\
& $( \pm 141)$ & $( \pm 0.01)$ & $( \pm 0.008)$ & $( \pm 350)$ & $( \pm 0.01)$ & $( \pm 0.8)$ & $( \pm 141)$ & $( \pm 10)$ \\
3 & 22800 & 5.34 & 0.275 & 24000 & 5.35 & 7.0 & 63000 & 786 \\
& $( \pm 145)$ & $( \pm 0.01)$ & $( \pm 0.007)$ & $( \pm 275)$ & $( \pm 0.01)$ & $( \pm 1.0)$ & $( \pm 473)$ & $( \pm 3)$ \\
\hline
\end{tabular}

The $\tan \delta_{\max }$, which indicates the beginning of the conversion of a liquid-like system into a gel, was decreased with increasing SCN concentration. The Tukey test showed that $\tan \delta_{\max }$ decreased in the following order: $0 \%$ $\mathrm{SCN}>1 \% \mathrm{SCN}>2 \% \mathrm{SCN}>3 \% \mathrm{SCN}$. The increased in SCN concentration resulted in increased number of casein micelles and thus in increased possibilities of interactions to be formed between destabilized molecules, even at higher $\mathrm{pH}$ values. The increased number of caseins required less charge reduction in order the molecules to come closer and thus the reduction in $\tan \delta$ values started at higher $\mathrm{pH}$ values. Indeed according to ANOVA, the $\mathrm{pH}_{\text {tanomax }}$ increased with increasing $\mathrm{SCN}$ concentration. The Tukey test showed that $\mathrm{pH}_{\text {tanomax }}$ increased in the following order:

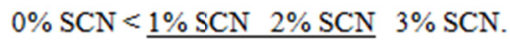

The lines indicate the overlapping differences. The decreased values of $\tan \delta_{\max }$ are due to the larger size of casein micelles, because the aggregation of proteins started at higher $\mathrm{pH}$ values, where the amount of colloidal calcium phosphate dissociated from the casein micelles into the milk serum was lower.

The increased values of $t_{\text {tanomax }}$ with increasing SCN concentration are due to the increased buffering capacity of caseins, which results in more lactic acid production for $\mathrm{pH}$ reduction. The $\mathrm{t}_{\text {tanomax }}$ values increased in the following order: $0 \% \mathrm{SCN}=1 \% \mathrm{SCN}<2 \% \mathrm{SCN}<3 \% \mathrm{SCN}$.

The $\mathrm{G}_{\text {tanomax }}$ reduced with increasing SCN concentration. According to Tukey test, the $\mathrm{G}_{\text {tanomax }}$ decreased in the following order: $0 \% \mathrm{SCN}>1 \% \mathrm{SCN}>2 \% \mathrm{SCN}>3 \% \mathrm{SCN}$. This can be attributed to the earlier destabilization of proteins (at higher $\mathrm{pH}$ values), where the repulsion forces among molecules are still strong and the interactions formed are weaker.

Finally, the $\mathrm{G}_{\max }^{\prime}$ increased with increasing $\mathrm{SCN}$ concentration. The Tukey test showed that $\mathrm{G}_{\max }^{\prime}$ increased in the following order: $0 \% \mathrm{SCN}<1 \% \mathrm{SCN}<2 \% \mathrm{SCN}<3 \% \mathrm{SCN}$. Similar results were reported for kefir samples enriched with SCN. According to Dimitreli and Antoniou (2011) the apparent viscosity of kefir samples was increased with increasing SCN concentration. Yovanoudi, Dimitreli, Raphaelides and Antoniou (2013) reported increased values of elongational viscosity and apparent viscosity for kefir-type samples, when the amount of SCN was increased. Caseins, due to their increased size (micelles) and their increased number of active side groups, play the most important role during gel formation. When the number of casein molecules is increased, more interactions can be formed that result in a dense matrix with increased elasticity and thus increased 
solid-like behavior.

\section{Conclusion}

The presence of SCN into the system of kefir greatly affected the formation of the gel and thus the properties of the final product. SCN increased the fermentation time required for the onset of gelation as well as for the $\mathrm{pH}$ to reach 4.6. The beginning of cross-linking of proteins towards aggregates that leads to the formation of a three-dimensional protein matrix, took place at higher $\mathrm{pH}$ values with increasing $\mathrm{SCN}$ concentration. The values of $\mathrm{G}^{\prime}$ and $\tan \delta$ that correspond to this point decreased with increasing SCN content. SCN addition enhanced the elasticity of the protein matrix and reduced the liquid-like behavior of the final products resulting in increased values of $\mathrm{G}_{\text {max }}^{\prime}$ and decreased values of $\tan \delta$.

\section{Acknowledgments}

This research has been co-financed by the European Union (European Social Fund - ESF) and Greek national funds through the Operational Program "Education and Lifelong Learning" of the National Strategic Reference Framework (NSRF) - Research Funding Program: ARCHIMEDES III. Investing in knowledge society through the European Social Fund. The authors thank Mr Kleonas Tsakmakidis (Hellenic Protein S.A.) for the supply of the SCN.

\section{References}

Dimitreli, G., \& Antoniou, K. D. (2011). Effect of incubation temperature and caseinates on the rheological behavior of kefir. Procedia Food Science, 1, 583-588. http://dx.doi.org/10.1016/j.profoo.2011.09.088

Farnworth, E. R. (2005). Kefir - a complex probiotic. Food Science and Technology Bulletin, 2, 1-17. http://dx.doi.org/10.1616/1476-2137.13938

Haque, A., Richardson, R. K., \& Morris, E. R. (2001). Effect of fermentation temperature on the rheology of set and stirred yogurt. Food Hydrocolloids, 15, 593-602. http://dx.doi.org/10.1016/S0268-005X(01)00090-X

Koroleva, N. S. (1988). Starters for fermented milks. Bulletin of the International Dairy Federation, 227, 35-40.

Kristo, E., Miao, Z., \& Corredig, M. (2011). The role of exopolysaccharide produced by Lactococcus lactis subsp. cremoris in structure formation and recovery of acid milk gels. International Dairy Journal, 21, 656-662. http://dx.doi.org/10.1016/j.idairyj.2011.02.002

Lakemonda, C. M. M., \& van Vliet, T. (2008). Acid skim milk gels: The gelation process as affected by preheating pH. International Dairy Journal, 18, 574-584. http://dx.doi.org/10.1016/j.idairyj.2007.11.001

Lazaridou, A., Serafeimidou, A., Biliaderis, C. G., Moschakis, T., \& Tzanetakis, N. (2014). Structure development and acidification kinetics in fermented milk containing oat $\beta$-glucan, a yogurt culture and a probiotic strain. Food Hydrocolloids, 39, 204- 214. http://dx.doi.org/10.1016/j.foodhyd.2014.01.015

Lee, W. J., \& Lucey, J. A. (2006). Impact of gelation conditions and structural breakdown on the physical and sensory properties of stirred yogurts. Journal of Dairy Science, 89, 2374-2385. http://dx.doi.org/10.3168/jds.S0022-0302(06)72310-4

Lucey, J. A. (2004a). Cultured dairy products: an overview of their gelation and texture properties. International Journal of Dairy Technology, 57, 77-84. http://dx.doi.org/10.1111/j.1471-0307.2004.00142.x

Lucey, J. A. (2004b). Formation, structural properties and rheology of acid-coagulated milk gels. In P. F. Fox, P. L. H. McSweeney, T. M. Cogan \& T. P. Guinee (Eds), Cheese: Chemistry, physics and microbiology, Third edition- Volume I: General aspects (pp. 105-122). Amsterdam, Boston, Heidelberg, London, New York, Oxford, Paris, San Diego, San Francisco, Singapore, Sydney, Tokyo: Elsevier Ltd.

Lucey, J. A., \& Singh, H. (1998). Formation and physical properties of acid milk gels: A review. Food Research International, 30, 529-542. http://dx.doi.org/10.1016/S0963-9969(98)00015-5

Lucey, J. A., Munro, P. A., \& Singh, H. (1998a). Rheological properties and microstructure of acid milk gels as affected by fat content and heat treatment. Journal of Food Science, 63, 660-664. http://dx.doi.org/10.1111/j.1365-2621.1998.tb15807.x

Lucey, J. A., Tamehana, M., Singh, H., \& Munro, R. A. (1998b). Effect of interactions between denatured whey proteins and casein micelles on the formation and rheological properties of acid skim milk gels. Journal of Dairy Research, 65, 555-567.

Mellema, M., Walstra, P., van Opheusden, J. H. J., \& van Vliet, T. (2002). Effects of structural rearrangements on the rheology of rennet-induced casein particle gels. Advances in Colloid and Interface Science, 98, 


\section{5-50. http://dx.doi.org/10.1016/S0001-8686(01)00089-6}

Otles, S., \& Cadingi, O. (2003). Kefir: A probiotic dairy - composition, nutritional and therapeutic aspects. Pakistan Journal of Nutrition, 2, 54-59.

Ozcan, T., Horne, D. S., \& Lucey, J. A. (2015). Yogurt made from milk heated at different pH values. Journal of Dairy Science, 98, 6749-6758. http://dx.doi.org/10.3168/jds.2015-9643

Ozcan-Yilsay, T., Lee, W. L., Horne, D., \& Lucey, J. A. (2007). Effect of trisodium citrate on rheological and physical properties and microstructure of yogurt. Journal of Dairy Science, 90, 1644-1652. http://dx.doi.org/10.3168/jds.2006-538

Peng, Y., Horne, D. S., \& Lucey, J. A. (2010). Physical properties of acid milk gels prepared at $37^{\circ} \mathrm{C}$ up to gelation but at different incubation temperatures for the remainder of fermentation. Journal of Dairy Science, 93, 1910-1917. http://dx.doi.org/10.3168/jds.2009-2792

Petridis, D., Dimitreli, G., Chrysalidou, S., \& Akakiadou, P. (2013). Optimization of the rheological and sensory properties of stirred yogurt as affected by chemical composition and heat treatment of buffalo milk. Journal of Food Research, 2, 55-70. http://dx.doi.org/10.5539/jfr.v2n6p55

Salaün, F., Mietton, B., \& Gaucheron, F. (2005). Buffering capacity of dairy products. International Dairy Journal, 15, 95-109. http://dx.doi.org/10.1016/j.idairyj.2004.06.007

Saunders, P. S., \&Ward, A. G. (1953). An absolute method for the rigidity modulus of gelatine gel. In V. G. W. Harrison (Ed.), Proceedings of the second international congress on rheology (pp. 284-290). UK: Butterworths.

Tamime, A. Y., \& Robinson, R. K. (2007). Tamime and Robinson's yogurt. Science and technology (3rd Ed.). Boca Raton, Boston, New York, Washington, DC: CRC Press.

Walstra P., Wouters J. T. M., \& Geurts T. J. (2006). Dairy Science and Technology (2nd Ed.). Taylor \& Francis, CRC Press, Boca Raton, London, New York.

Xu, Z. M., \& Raphaelides, S. N. (2005). A dynamic U-tube rheometer of novel design for the study of weak gels and foams. Rheologica Acta, 45, 77-82. http://dx.doi.org/10.1007/s00397-005-0451-6

Xu, Z., Emmanouelidou, D. G., Raphaelides, S. N., \& Antoniou, K. D. (2008). Effects of heating temperature and fat content on the structure development of set yogurt. Journal of Food Engineering, 85, 590-597. http://dx.doi.org/10.1016/j.jfoodeng.2007.08.021

Yovanoudi, M., Dimitreli, G., Raphaelides, S. N., \& Antoniou, K. D. (2013). Flow behavior studies of kefir type systems. Journal of Food Engineering, 118, 41-48. http://dx.doi.org/10.1016/j.jfoodeng.2013.03.036

\section{Copyrights}

Copyright for this article is retained by the author(s), with first publication rights granted to the journal.

This is an open-access article distributed under the terms and conditions of the Creative Commons Attribution license (http://creativecommons.org/licenses/by/3.0/). 